\title{
Francis Rohmer: from the neurological ward to Dachau and back
}

\author{
Francis Rohmer: da enfermaria neurológica a Dachau e de volta \\ Raimundo Nonato Delgado RODRIGUES ${ }^{1}$
}

\begin{abstract}
The author presents a brief synopsis of the life and works of Professor Francis Rohmer, a French neurologist whose great relevance to the development of the French Neurological Society is only outshined by his humanistic role, in spite of harsh conditions, when a prisoner at the Dachau Concentration Camp in Germany, during World War II.
\end{abstract}

Keywords: Neurology history.

RESUMO

O autor apresenta uma breve revisão da vida e obra do Prof. Francis Rohmer, neurologista francês, cuja enorme relevância para o desenvolvimento da Sociedade Neurológica Francesa foi apenas ultrapassada pelo seu papel humanístico a despeito de condições difíceis quando prisioneiro no Campo de Concentração alemão de Dachau durante a Segunda Guerra Mundial.

Palavras-chave: História da Neurologia.

Francis Camille Rohmer was born on February 20, 1915, at Colmar in German Alsace. He graduated from Strasbourg medical school in the late '30s and did his residency training (Interne des Hôpitaux) under Prof. Jean Alexandre Barré, who had a huge influence in developing his lifelong passion for Neurology ${ }^{1}$.

In September 1939, World War II broke out and the French government called for a general mobilization. In 1940, Rohmer had the opportunity to study for a short time with Prof. Théophile Alajouanine ${ }^{2}$. With the German invasion, the latter young doctor was subsequently conscripted into the army medical corps, participated in the ill-fated Ardennes Campaign and became a prisoner of war.

After demobilization, in October 1940, Rohmer joined his former professor, Dr. Barré, at Clermont-Ferrand at the center of France, to where Strasbourg University had withdrawn, in order to escape the attempts of Nazification in Alsace.

The University of Strasbourg had become a center of the resistance against the German invader from July 1940, echoing the national indignation against France's defeat. Needless to say, it became a matter of national pride for the Third Reich to bring all the university refugees back to Alsace ${ }^{3}$.
This was the political scene when Rohmer assumed his post at the Hôtel-Dieu Hospital in 1940.

In spite of this, the next two years were prolific. He passed his doctorate thesis in Neurology, obtained a Diploma of Forensic Medicine and Psychiatry and became the clinic head (chefde clinique) (Figure). Moreover, during these first months in his new ward, he published eight articles and clinical cases in the annals of congresses in France and Switzerland ${ }^{4}$. His interest in Neurology made him work hard and travel a great deal, attending scientific meetings. In Marseille, he was introduced to electroencephalography ${ }^{1}$.

He also became progressively involved with the Resistance movement. During these trips, he distributed tracts and clandestine newspapers, which was extremely dangerous, and also collaborated by hiding on-the-run guerrillas, who were being sought out by the Gestapo, providing medical assistance to Resistance groups, eventually serving as a "letter-box" for them [Prof. Vincent Rohmer, personal communication].

Because of its political visibility and symbolic meaning, the exiled Strasbourg University was hit harder still in 1944. The Germans increased their raids to capture students and professors. On March 8, a particular raid took place at the

1 Universidade de Brasília, Faculdade de Medicina, Brasília DF, Brasil.

Raimundo Nonato Delgado Rodrigues (iD) https://orcid.org/0000-0002-1119-9807

Correspondence: Raimundo Nonato Delgado Rodrigues; SQNW, 311 Bloco C / apt. 208A - Setor Noroeste; 70687-315 Brasília DF, Brasil; E-mail: nonatodelgado@gmail.com

Conflict of interest: There is no conflict of interest to declare.

Received 30 January 2019; Received in final form 22 April 2019; Accepted 24 April 2019. 


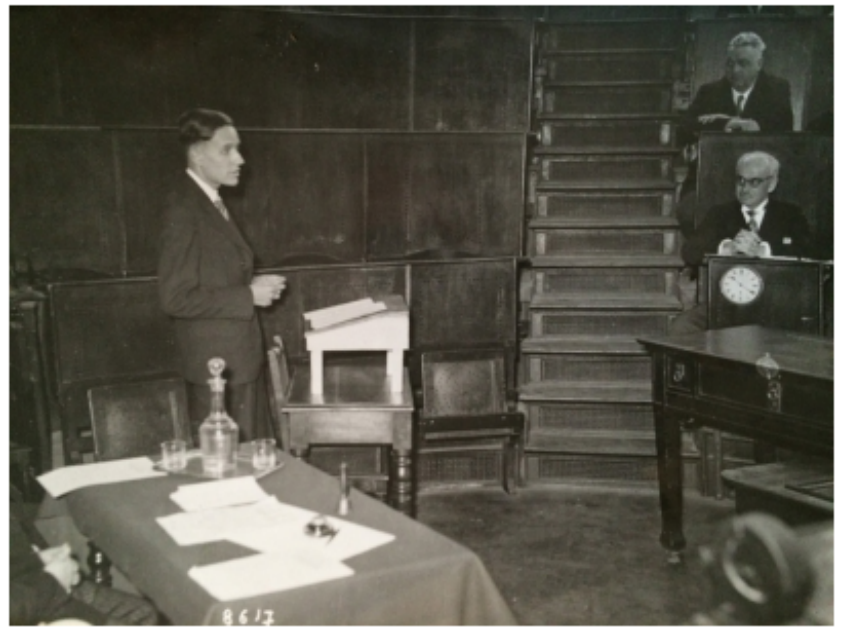

Figure. Dr. Rohmer defending his doctorate thesis De l'intérêt du syndrome pyramidal déficitaire dans le diagnostic des tumeurs des hémisphères cérébraux. Facing him, in the first row, is Professor J.A. Barré. Strasbourg, circa 1940. (Courtesy of Prof. Vincent Rohmer, personal archives)

Hôtel-Dieu Hospital to seize doctors considered to be particularly active résistants ${ }^{3}$. Shamefully denounced by the hospital director, Dr. Rohmer and others were captured ${ }^{5}$. On July 2 , they boarded cattle wagons on a train heading for the concentration camp of Dachau, near Munich, in what was later called "The Convoy of Death"

During the height of summer, more than 2,500 prisoners were transported, with no water or food, divided into groups of 100 people in wagons made for 50 , subjected to the violence of the guards and the uncertainty about their destination.

Dr. Rohmer later described ${ }^{5}$ the morbid atmosphere inside the boxcar, the attempts to keep a minimum of social order among the desperate prisoners and, with a sharp eye, he reported on the deterioration of the passengers' state of health. He described the onset of cases of asphyxia, hyperthermia, dehydration and syncope, delirious violence culminating with corporal fighting and sudden death by exhaustion. Seventy-four deaths in about three hours.

Very pungently, he reported his own panic attack: tingling sensations and finger numbness, cramps, tetanic contraction of his hands", difficulties in speech, and hyperventilation. "I only feared that one of those lunatics would overpower me, because of the state I was in, I would never be able to defend myself", he wrote ${ }^{5}$.

In another part, Dr. Rohmer narrated the situation of a young man seated in front of him whose respiratory rate was slowing down. He witnessed, in a matter of minutes, the onset of a myotic state and a sudden right and then left mydriasis, followed by respiratory arrest. Maybe the evolution of intracranial bleeding caused by head trauma? "Nothing to do", he remembered, "another one is gone..."

After three days of unutterable suffering, the convoy finally arrived at Dachau.
This camp, dedicated to the internment of political prisoners, developed a terrible reputation for being the center for horrifying medical experiments ${ }^{7}$. After some weeks there, Dr. Rohmer was transferred to a smaller camp, in a gypsite mining facility. At this camp, in his own words, "there was no need for gas chambers as people here died of exhaustion at work" ${ }^{8}$. Fortunately, after a few weeks and, thanks to the influence of the camp's physician, he was transferred to the sickbay as one of the doctors. There he did his best to help the sick prisoners and, indeed, risked his own life by stealing medicine from the camp guards. Sometimes he even managed to hospitalize a few fellow inmates, if only to keep them from dying of exhaustion ${ }^{1}$.

The camp was liberated by the American Army on April 3, 1945. Dr. Rohmer arrived back in Strasbourg some days later in striped pajamas and in a poor state of health ${ }^{8}$.

Not long after his release from prison in Germany, he was back at his hospital, working in the neurological ward, conducting "bedside" clinical practice and teaching. He became an associate professor (professeur agregé) in 1950.

He remained in the neurological services at Strasbourg University Hospital from 1968 until his retirement in 1982. He collaborated in the development of the French Neurological Society, which he presided over in 1980, and became a member of the Revue Neurologique editorial board $^{2}$. Prof. Rohmer was one of the great enthusiasts for the implementation of electroencephalography as a diagnostic tool in Neurology and also chaired the French Society of Electroencephalography.

Among his scientific work, we find journal publications, scientific research, and theses. Curiously, some of his articles were published when he was already interned at Dachau, in 1944. It is inspiring to observe that his only publication in 1945 was in June, hardly two months after his liberation ${ }^{4}$ !

The experience of living under such inhumane conditions left scars on the flesh and in the soul of all survivors. To some, it represented being condemned to death, even if their bodies had survived the torment. For others, and we believe this was the case for Prof. Rohmer, the hardships and sufferings only made them more determined to survive and to keep the essence of humanity alive in their spirit. His fruitful life after Dachau-his achievements as an instructor of young doctors, his sensibility and cordiality towards those in pain-is a testimony of an undying faith in mankind, surviving way beyond the barbed wires of hatred and intolerance.

\section{ACKNOWLEDGMENTS}

The author thanks Prof. Vincent Rohmer and the technical personnel at Bibliothèque de l'Académie de Médecine, Paris, for the valuable information provided to clarify important aspects of Prof. Rohmer's life and works. 


\section{References}

1. Rohmer CM. Eloge Funebre. Strasbourg; 2008.

2. Cambier J. Francis Rohmer (1915-2008). Rev Neurol (Paris). 2009;165(2):125-6. https://doi.org/10.1016/j.neurol.2009.01.001

3. Moulin JP. L' exil de L'Université de Strasbourg à Clermont-Ferrand». Le Patriot Resist. 2016;908:10-3.

4. Rohmer F. Titres et travaux scientifiques. Strasbourg; 1961.

5. Rohmer F. Le Convoi de la Mort. In: Braun L. De l' Université aux camps de concentration temoignages. 4 eme ed. Strasbourg: Strasbourg Presses Universitaires; 1996. p. 57-66.
6. Delvaux M, Fontaine P, Bartsch P, Fontaine OT.

Tétanie, spasmophilie, syndrome d'hyperventilation:

synthèse théorique et thérapeutique. Rev Med Liege. 1998 Jan;53(1):1-22.

7. Berger RL. Nazi science: the Dachau hypothermia experiments. N Engl J Med. 1990 May;322(20):1435-40. https://doi.org/10.1056/NEJM199005173222006

8. Rohmer F. Souvenirs du Prof. Rohmer. Quotid du médecin. 2005. equotidiendumedecin.fr/recherche?search_text_form=rohmer 